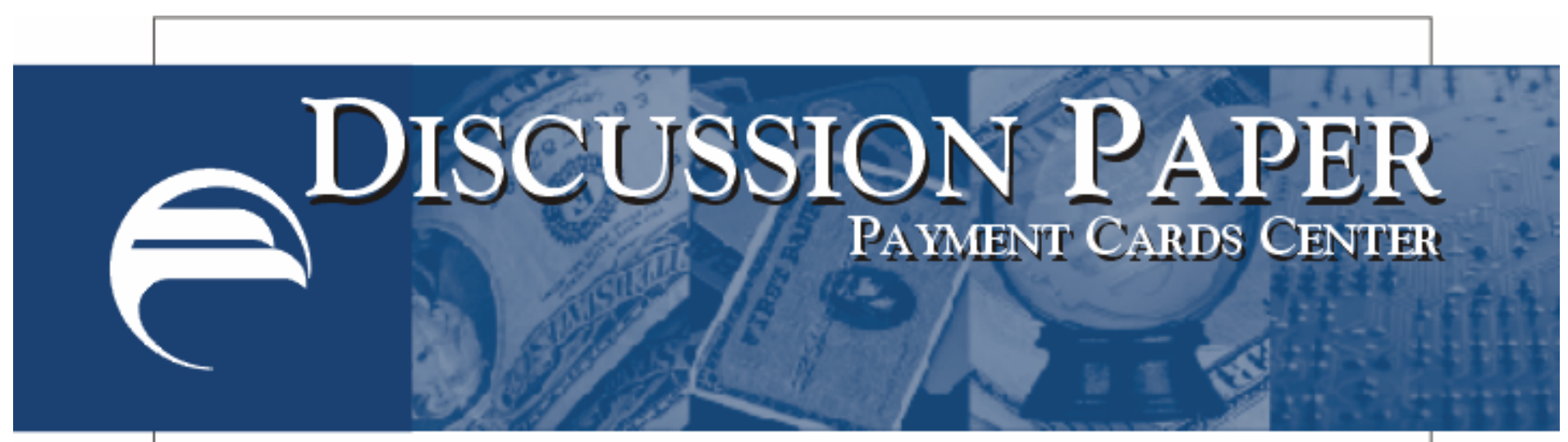

\title{
Proposed Changes to Regulation Z: Highlighting Behaviors That Affect Credit Costs
}

\author{
Ann Kjos*
}

March 2008

\begin{abstract}
Summary: On June 29, 2007, the Payment Cards Center of the Federal Reserve Bank of Philadelphia sponsored a workshop led by Jeanne Hogarth, program manager, Consumer Education and Research Section, Division of Consumer and Community Affairs, Federal Reserve Board of Governors, to discuss the Board's proposed changes to disclosure requirements for open-end credit, in particular, credit card billing statements and solicitation materials. Hogarth tied the proposed changes to her own research that identified certain behaviors most likely to affect the interest rates consumers pay for credit card borrowing. Given these research findings, Hogarth argued that having access to easily understood information about critical credit card terms and conditions can help consumers make more financiallv efficient decisions.
\end{abstract}

*Payment Cards Center, Federal Reserve Bank of Philadelphia, Ten Independence Mall, Philadelphia, PA 19106. The views expressed here are not necessarily those of this Reserve Bank or of the Federal Reserve System.

\section{Federal Reserve Bank of Philadelphia}




\section{Introduction}

On June 29, 2007, the Payment Cards Center of the Federal Reserve Bank of Philadelphia hosted a workshop led by economist Jeanne Hogarth, program manager, Consumer Education and Research Section, Division of Consumer and Community Affairs, Federal Reserve Board of Governors. ${ }^{1}$ Hogarth joined the Board in 1995 and has conducted research and outreach initiatives focused on consumers' use of credit cards, consumer protection strategies, and financial literacy and education. The purpose of Hogarth's workshop was to discuss the Board's proposed changes to disclosure requirements for “open-end credit," in particular, credit card billing statements and solicitation materials.

These proposed changes are part of the first complete revision since 1981 of Regulation Z, the set of rules that implement the Truth in Lending Act (TILA). TILA, enacted in 1968, is intended to protect borrowers by requiring lenders to disclose key terms and costs of open-end (revolving) and closed-end (installment) consumer credit arrangements. ${ }^{2}$ In the last quarter century, credit card use has grown exponentially, with credit card transactions making up 23.3 percent of noncash payments in $2006 ;^{3}$ at the same time, the credit card market has become more complex. Aided by advances in technology that have enabled such innovations as risk-based pricing, discussed in more detail later, credit card pricing terms and conditions have evolved into a far more complicated structure since the enactment of TILA.

\footnotetext{
${ }^{1}$ In the Purposes \& Functions statement for the Division of Consumer \& Community Affairs it is stated that "among the Federal Reserve's responsibilities in this area are: writing and interpreting regulations to carry out many of the major consumer protection laws; reviewing bank compliance with the regulations; investigating complaints from the public about state member banks' compliance with consumer protection laws; addressing issues of state and federal jurisdiction; testifying before Congress on consumer protection issues; and conducting community development activities." For more information on the role of Community Affairs in the Federal Reserve System, visit http://www.federalreserve.gov/pf/pdf/pf_6.pdf.

${ }^{2}$ For a summary of proposed changes and for background on TILA, see the publication from the Federal Reserve Bank of Philadelphia's Research Department, Banking Legislation \& Policy, Volume 26, Number 2 (April - June 2007). www.philadelphiafed.org/files/blp/blpq207.pdf.

${ }^{3}$ Statistics are from The 2007 Federal Reserve Payments Study: Noncash Payment Trends in the United States: 2003-2006. www.frbservices.org/files/communications/pdf/research/2007_payments_study.pdf
} 
In addition to increasingly complex lending rate structures, credit card pricing has been further complicated by a range of new fee categories, balance computation differences, and other changes to once fairly standardized terms and conditions. ${ }^{4}$ This complexity, however, has elicited increased concern from consumers, legislators, and regulators about the effectiveness of current disclosures, ${ }^{5}$ prompting the Federal Reserve to announce in December 2004 that it would begin a process to evaluate the current disclosure rules under Regulation $\mathrm{Z}$ and propose changes as needed. After three years of deliberation, which included extensive testing to gauge the effectiveness and consumers' comprehension of different model disclosure forms, the Board released the proposed revision in the summer of $2007 .{ }^{6}$

To set the stage for her discussion of specific recommendations in the proposal, Hogarth first outlined findings from her own research that identified certain behaviors most likely to affect the interest rates consumers may pay for credit card borrowing. Her research was conducted with two co-authors, Amberly Hazembuller and Britton Lombardi. Their paper (published in 2007 in the American Council on Consumer Interests’ Annual, Volume 53), titled “Unlocking the RiskBased Pricing Puzzle: Five Keys to Cutting Credit Card Costs,"7 demonstrated that five specific behaviors had a statistically significant effect on the interest rate consumers were charged on credit cards. Hogarth's key conclusion for consumers was that behaviors affect the interest rate paid and changing behaviors may lead to lower interest rates. Given these research findings,

\footnotetext{
${ }^{4}$ Mark Furletti’s paper “Credit Card Pricing Developments and Their Disclosure” from the Payment Cards Center describes in greater detail how credit card pricing has evolved and become more complex. http://www.philadelphiafed.org/pcc/papers/2003/CreditCardPricing_012003.pdf

${ }^{5}$ See the Payment Cards Center's Conference Summary, "Federal Consumer Protection Regulation: Disclosures and Beyond,” June 10, 2005, which summarizes a discussion among business executives, economists, federal regulators, and others on the many challenges involved in developing effective consumer disclosures for open-end credit.

${ }^{6}$ The proposed rules can be found on the Federal Reserve Board's website or in the Federal Register: Truth in Lending; Proposed Rule, Federal Reserve System, June 14, 2007. http://edocket.access.gpo.gov/2007/pdf/07-2656.pdf

7 "Unlocking the Risk-Based Pricing Puzzle: Five Keys to Cutting Credit Card Costs" can be found at www.consumerinterests.org/files/public/HazembullerLombardiHogarth_UnlockingtheRiskBasedPricingPu zzle.pdf.
} 
Hogarth argued that having access to easily understood information about critical credit card terms and conditions can help consumers make more efficient financial decisions. Furthermore, the regulatory process can facilitate this outcome through effective mandatory disclosures.

This paper summarizes the workshop, including a discussion of Hogarth’s research and how several of the proposed revisions to Regulation $\mathrm{Z}$ relate to her key research findings.

\section{Five Keys to Cutting Credit Card Costs}

Hogarth’s research paper analyzes risky financial behaviors and how those behaviors are reflected in the annual percentage rates (APRs) ${ }^{8}$ consumers are charged. As she explained, this work was motivated by several related questions: How are risky behaviors reflected in credit card interest rates? Are any risky behaviors "worse" than others? What advice can we offer consumers? And how does what we learn relate to disclosure?

Hogarth began her presentation with a brief description of risk-based pricing and how the methodology employed for her and her co-authors' study attempted to link pricing and behaviors. She then discussed in more detail the five key behaviors they found to be the most influential in determining an individual's interest rate for credit cards. As Hogarth explained, risk-based pricing methodologies are used by credit card issuers to assign different interest rates to borrowers based on their relative risk. Consumer lenders typically begin their decision process using an individual's credit score. A credit score is broadly defined as "a number generated by a statistical model which is used to objectively evaluate information that pertains to making a credit decision."9 Scores that measure a consumer's risk of default can be purchased from specialized providers such as Fair Isaac or the major credit reporting agencies (CRAs), Experian, TransUnion, and Equifax.

\footnotetext{
${ }^{8}$ The Federal Reserve defines an annual percentage rate as "the way of stating the interest rate you will pay if you carry over a balance, take out a cash advance, or transfer a balance from another card. The APR states the interest rate as a yearly rate.” www.federalreserve.gov/Pubs/shop/

${ }^{9}$ See Fair Isaac's website: www.myfico.com.
} 
In the paper, the authors discuss in detail five variables used to calculate a credit score: (1) types of loans used (i.e., mortgage or open-line), (2) new credit (i.e., number of recent credit inquiries), (3) length of credit history with lenders, (4) the amounts owed and available open credit, and (5) payment history (i.e., record of timely payments on all reported credit relationships). As the authors note, borrowers' behavior in relation to any of these factors may influence their credit score and thereby affect the interest rates they are charged by lenders. To gain insight into these dynamics and examine which behaviors seem to be most influential in determining APRs, the authors used data from the Survey of Consumer Finances (SCF) to explore what consumers say about their own financial behaviors in comparison to their reported costs associated with accessing open-end credit.

The Federal Reserve System conducts the Survey of Consumer Finances every three years. The study’s data come from the 2004 Survey (the 2007 survey results will be released later in 2008). This nationally representative survey of U.S. households asks respondents to provide information on a wide range of financial activities, including their use of credit cards. As the Federal Reserve website notes, “The main purpose of the survey is to help the government and, ultimately, the public at large understand the financial condition of families in the United States and to study the effects of changes in the economy." ${ }^{10}$ Hogarth and her colleagues used the SCF to examine the relationships between risky behaviors and the price paid for credit, with the interest rate on the primary credit card set as the dependent variable. ${ }^{11}$

Their analysis tested a number of factors that might be expected to correlate with interest rates. In the end, the authors focused on five key behaviors that proved to be statistically significant: paying off credit card balances, paying bills on time, shopping for credit, becoming more financially educated, and decreasing credit use. Credit reports do not provide information

\footnotetext{
10 The 2004 report on the Survey of Consumer Finances can be found on the Federal Reserve Board's website at: www.federalreserve.gov/pubs/oss/oss2/2004/scf2004home.html.

${ }^{11}$ For more details on dependent and independent variables used in the model, see page 75 of Hogarth and co-authors' paper.
} 
on a number of consumer characteristics, including income, education, race, and nature of employment. Not surprisingly, these factors, as reflected in the SCF, were not significantly correlated with interest rates.

\section{A. Paying Off the Credit Card Balance}

As Hogarth discussed, their findings showed that consistently paying off credit card balances had an important effect in lowering APRs. However, many consumers are not able to pay off their entire balance with one payment. For these consumers, Hogarth noted that initiating a new pattern of increasing monthly payments will significantly lower the total interest costs, since the loan balance will decline more rapidly than if these consumers had not increased payments.

\section{B. Paying Bills on Time}

The research also indicated that consumers who consistently paid their bills on time had lower interest rates than those who missed payments. Missing monthly credit card payments can trigger a "penalty rate.” Credit card risk models generally assign a higher risk to borrowers who fail to make monthly payments on time. According to Consumer Action’s 2007 Credit Card Survey, the average penalty rate was 24.51 percent and as high as 32.24 percent in $2007 .^{12}$ C. Shopping for Credit

Hogarth discussed another consumer behavior that has become more prevalent in the last decade: comparison shopping for credit cards. As the industry has become more competitive and as it has increased its marketing efforts, consumers have more opportunities to compare offers from credit card lenders. At the same time, newspaper coverage and consumer-oriented websites have expanded the information available on alternative credit card options. Hogarth's analysis confirmed that consumers who acknowledge shopping for the best credit card deal were more

\footnotetext{
12 Consumer Action, founded in 1971, is a nonprofit consumer advocacy organization based in San Francisco. http://www.consumer-action.org/news/articles/2007_credit_card_survey/.
} 
likely to find lower interest rates. As Hogarth noted, and later related to disclosure policy, one implication for these findings is that consumers armed with more information about what to look for and how to find it are able to make better-informed decisions when choosing a credit product.

\section{Becoming More Financially Educated}

In designing their research, Hogarth and co-authors hypothesized that having a higher level of financial education could also be a factor leading to a reduction in interest rates. Since the SCF has no such direct indicator, they used respondents' expressions of risk tolerance as a proxy for financial sophistication. The intuition was that those consumers who have a greater understanding of financial products and who are investing in relatively sophisticated instruments, such as stocks and bonds, and using more complex credit products are more likely to take on better-informed risk. As is the case with the behavior described under Shopping for Credit, consumers with a higher level of financial sophistication may have a better understanding of credit card offerings than those with a lower risk tolerance, which allows them to select the most beneficial credit card product for their situation.

\section{E. Decreasing Credit Use}

Similar to the case when consumers pay off card balances more rapidly, behaviors that lead to relatively low utilization rates of available credit card lines were also found to correlate with lower APRs. Based on what SCF respondents reported as their average balance on credit cards used and what they reported as their cards' maximum credit limit, the authors calculated a utilization ratio. The analysis confirmed that consumers who maintained relatively lower utilization rates on their available cards also paid lower interest rates. Moreover, the analysis showed that changes in utilization rates of as little as 10 percent led to a significant change in borrowing costs.

The overall research findings confirmed that financial behaviors do matter in determining how much consumers pay for credit. The next question addressed in the workshop was how such 
insight could be used to design more effective credit card disclosures that motivate consumers to positively alter these behaviors. This, of course, has been the Board's challenge in developing revisions to Regulation Z.

\section{Truth in Lending Act (TILA) and Regulation Z}

Before discussing the proposed revisions to Regulation Z, Hogarth provided a review of the Truth in Lending Act (TILA) and Regulation Z. She explained that Congress’ intent in enacting TILA in 1968 was to give consumers entering into credit transactions relevant information that would help them make better-informed choices. ${ }^{13}$ Congress asked the Federal Reserve to develop the specific rules needed to implement the legislation; these rules are codified in Regulation Z.

Regulation Z’s stated purpose is “to promote the informed use of consumer credit by requiring disclosures about its terms and costs." ${ }^{14}$ Specifically, the regulation gives consumers the right to cancel certain credit transactions that involve a lien on a house, provides the means for resolution of credit billing disputes, and defines information disclosure requirements for lenders. The regulation applies to individuals or businesses that offer or extend consumer credit if (1) the credit is offered to consumers, (2) the credit is offered on a regular basis, (3) the credit is subject to finance charges, and (4) the credit is primarily for personal, family, or household use. In keeping with Hogarth's remarks, this summary will focus on the terms of Regulation $\mathrm{Z}$ as they apply to credit card borrowing.

Since the enactment of TILA in 1968 there have been a number of changes to Regulation Z. Among the most substantive was the definition of a standard disclosure format that displays APR and fee information in a table format using a specific font size - the so-called Schumer

\footnotetext{
${ }^{13}$ A broader discussion of the legislative intent for the Truth in Lending Act can be found on the FDIC's website at www.fdic.gov/regulations/laws/rules/6500-1400.html.

${ }^{14}$ Regulation Z can be found at http://www.federalreserve.gov/regulations/default.htm\#z.
} 
box. ${ }^{15}$ Prior to the adoption of the Schumer box, much of the information concerning card rates and conditions were often in small print and difficult to locate. The implementation of the Schumer box has allowed consumers to easily find and compare the costs of credit card purchases. This change was mandated by the Fair Credit and Charge Card Disclosure Act of 1988.

Since that time, there have been few substantive changes to Regulation Z's disclosure requirements related to credit card borrowing. However, in May 2007, the Federal Reserve Board released a request for comments on the new proposed amendments to Regulation $\mathrm{Z}$ that address a wide range of credit card disclosure elements. ${ }^{16}$ While the intent of the comprehensive review is to ultimately address the full range of consumer credit, the first stage was focused on open-end credit accounts, mainly general-purpose credit cards. Other areas of Regulation Z, such as closedend mortgage credit, home equity lines of credit, and adjustable-rate mortgage loans, will be reviewed in subsequent stages.

The proposed changes to credit card disclosures resulted from an extensive review by Federal Reserve Board staff. The Board announced the review process in December 2004, when it issued an advance notice of proposed rulemaking (ANPR). The ANPR requested comments on issues relating to three categories: "the format of open-end credit disclosures, the content of the disclosures, and the substantive protections provided under the regulation.” ${ }^{17}$ In response, the Board received approximately 200 comments from industry sources and the public at large and an additional 2,500 responses to the final proposal.

\footnotetext{
${ }^{15}$ The Schumer box is named after New York Senator Charles Schumer, who wrote the provision that created the table (Schumer box) for the Truth in Lending Act. A press release announcing the legislation issued in 2000 by the Senate can be found www.senate.gov/ schumer/1Senator\%20Schumer\%20Website\%20Files/pressroom/press_releases/PR00315.html.

${ }^{16}$ The proposed amendments, along with sample models and forms, can be found on the Federal Reserve Board's website at: http://www.federalreserve.gov/newsevents/press/bcreg/20070523a.htm.

${ }^{17}$ The advance notice of proposed rulemaking (ANPR), Federal Reserve System, 12 CFR Part 226 [Regulation Z; Docket No. R-1217], can be found on the Board's website at: www.federalreserve.gov/BoardDocs/press/bcreg/2004/20041203/attachment.pdf.
} 
In addition to analyzing public comments, the Board made extensive use of consumer testing and focus groups to evaluate the effectiveness of alternative disclosure elements. Hogarth described how this relatively new innovation to the rule-making process added important insight into consumer perspectives of proposed disclosure content, definitions, and format. As the Board noted in the May 2007 press release announcing the proposed rule, “This testing helped us to identify the key information consumers need to make informed choices about how they use their accounts.”18

\section{The Federal Reserve Board's Proposed Changes to Regulation Z}

Hogarth discussed the proposed revisions, focusing on the rules pertaining to two critical sources of information that consumers use to understand credit card terms and conditions: the initial card solicitation and credit card billing statements. These documents give consumers information about credit offerings and update consumers on the status of open accounts, respectively. Hogarth described several of the proposed changes to credit card solicitations and billing statements that link to her research on consumer behaviors and their effect on borrowing costs.

\section{A. Proposed Disclosure Changes for Credit Card Solicitations}

Hogarth organized her discussion of the proposed rules for solicitation disclosures around three areas: disclosures of APRs, disclosures of ancillary fees, and information about disclosures on a website hosted by the Board of Governors. She noted that the Schumer box will remain a standard feature in credit card solicitations. The Board's analysis determined that the format has

\footnotetext{
${ }^{18}$ More comments on consumer testing as part of the Regulation $\mathrm{Z}$ review process can be found in the Federal Reserve press release at: http://www.federalreserve.gov/newsevents/press/bcreg/20070523a.htm.
} 
proven to be an effective way to highlight interest rates and fees. Therefore, many of the proposed changes focused on adding additional explanatory information.

\section{APRs}

The first proposed change to disclosures described by Hogarth related to variable APR rates and how they are applied to purchases. The Federal Reserve defines a "variable rate" as an APR that changes from time to time and, more specifically, that the "rate is usually tied to another interest rate, such as the prime rate or the Treasury bill rate.” ${ }^{19}$ The current rules mandate that the base interest rate be noted and the methodology used to calculate this rate be described, all within the Schumer box. The new rule would simplify the information disclosed in the Schumer box to indicate only that the APR will vary based on the market, along with a reference to the type of base rate, such as the prime rate. All other details would be disclosed elsewhere in the solicitation document. (See Table $1 .{ }^{20}$ )

Hogarth explained that through its testing, the Board found that consumers were often distracted or confused by the old format with its extensive details on variable rate calculations. These calculations were found to inhibit consumers' ability to easily compare credit card solicitations from multiple issuers. The intent of this proposed revision is to simplify the rate characteristics so as to make it easier for consumers to comparison shop for credit cards. As Hogarth noted, comparison shopping behaviors were found to be an important determinant in minimizing the costs of using credit cards.

\section{* Table 1}

Interest Rates and Interest Charges Annual Percentage Rate (APR) for Purchases $8.99 \%, 12.99 \%$, or $19.99 \%$ when you open your account, based on your credit worthiness.

After that, your APR will vary with the market based on the Prime Rate.

\footnotetext{
${ }^{19}$ For more Federal Reserve rate definitions, visit http://www.federalreserve.gov/Pubs/shop/.

${ }^{20}$ All of the tables in this summary are based on sample tables from the Board of Governors.
} 
Hogarth then discussed a second proposed revision for credit card solicitation documents: penalty APRs. The current rules require credit card issuers to disclose, inside the Schumer box, the APR that will apply in the event of the consumer's "default," with the actions that trigger the rate described outside the box. However, the Board's testing found that many consumers were confused by the term "default rate" and they could not easily locate the information that described how the rate is triggered.

Hogarth explained that the proposed changes are designed to lessen this confusion by eliminating the word "default” and substituting the more commonly understood term "penalty APR.” The proposed change will also require that the triggering actions for penalty rates be located inside the Schumer box. (See Table 2.) Hogarth also made note of the bottom section of the table, where another proposed change would mandate that the period of time in which the penalty rate is applied be clearly defined. Hogarth explained that these various changes should make it easier for consumers to compare offers and also make clear which penalties are associated with not paying bills on time, both behaviors that her research indicated can lead to lower credit costs.

\begin{tabular}{|c|c|}
\hline \multicolumn{2}{|r|}{ Interest Rates and Interest Charges } \\
\hline $\begin{array}{l}\text { Penalty APR and When } \\
\text { it Applies }\end{array}$ & $\begin{array}{l}\mathbf{2 8 . 9 9 \%} \\
\text { This APR may be applied to the entire balance of your account if } \\
\text { you: } \\
\text { 1) Make a late payment twice in a six-month period; } \\
\text { 2) Go over your credit limit twice in a six-month period; } \\
\text { 3) Make a payment that is returned; or } \\
\text { 4) Do any of the above on another account that you have with } \\
\text { us. }\end{array}$ \\
\hline & $\begin{array}{l}\text { How Long will the Penalty APR Apply?: ID your APRs are } \\
\text { increased for any of these reasons, the Penalty APR will apply until } \\
\text { you make six consecutive minimum payments when due and do not } \\
\text { exceed your credit limit during that time period. }\end{array}$ \\
\hline
\end{tabular}

Hogarth closed her discussion on disclosures for APRs in credit card solicitations by noting proposed changes for describing balance transfer and cash advance rates. (See Table 3.) 
The rules propose that the APRs for these borrowing categories be disclosed inside the Schumer box, grouped together with other interest rates that may apply.

Another new addition to the Schumer box would be a "Notice Regarding Interest Charges” that addresses payment allocation. For example, if consumers’ payments are to first be applied to transferred balances before higher rate purchase balances, this would be clearly disclosed.

As Hogarth explained, consumer testing revealed that the way in which many card issuers treat APRs and allocate repayment to balance transfers and cash advances was generally found to be confusing for consumers. By highlighting the terms in the Schumer box and using plain language, the Board hopes to better educate consumers about the somewhat confusing billing practices and in doing so provide for better-informed choices.

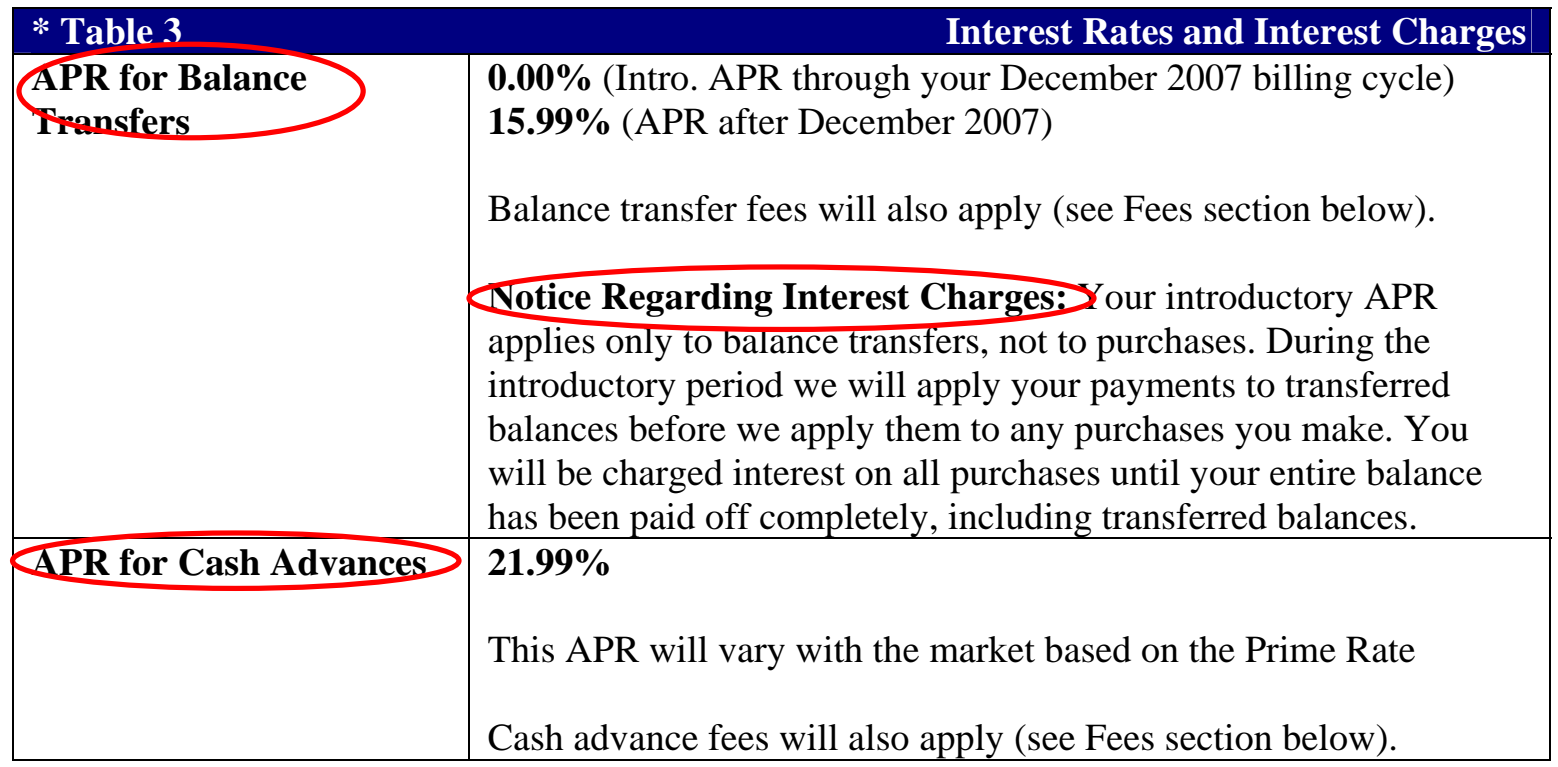




\section{Disclosure of fees}

Over the years, credit card issuers have introduced a number of new fee categories ${ }^{21}$ that consumer testing revealed add to consumers' confusion and, of course, increased costs for those who find themselves subject to such fees. As Hogarth noted, current disclosure practices generally mean that, in the solicitation offering, many of these fees are described in the small print outside the Schumer box. Consumer testing revealed that many of the fees go unnoticed, creating confusion about how they may affect a new credit card customer.

In her remarks Hogarth focused on two types of fees: set-up and maintenance fees and penalty fees. Set-up and maintenance fees described in the example disclosure in Table 4 are often associated with nontraditional, low-limit, higher risk accounts, which tend to have more complex fee structures. By putting disclosures in one easy-to-understand format, the Board hopes to help these borrowers gain a better understanding of the full cost of the credit offered and, as a result, make better-informed choices as they shop for credit.

Hogarth then described the proposed disclosure changes for penalty fees. She noted that the penalty fees section of the table would cross-reference the penalty APR section if, for example, going over the credit limit would invoke the penalty APR rate as well. The crossreference would ensure that consumers understand that late payments induce fees and that penalty APRs may be triggered.

These disclosures tie to Hogarth's research on lower credit costs. For example, the prominently labeled and detailed explanation of late charges emphasize the costs of not making timely payments and over-the-credit-limit fee disclosures play a similar role and may also affect behaviors related to utilization rates.

\footnotetext{
${ }^{21}$ Mark Furletti’s paper "Credit Card Pricing Developments and Their Disclosure” from the Payment Cards Center describes in greater detail how credit card pricing has evolved and new fee categories have emerged. http://www.philadelphiafed.org/pcc/papers/2003/CreditCardPricing_012003.pdf
} 


\section{Board of Governors' website}

The last change for solicitation disclosures that Hogarth discussed directly addressed the research finding on the relevance of financial literacy. The proposed rule would require credit card issuers to include a reference on all credit card solicitations to a new informational website hosted by the Federal Reserve. The website would have additional information and consumerfriendly advice on how to compare credit card offers and describe which factors are most important to consider when shopping for credit. This information would supplement the more formal disclosure information contained in the solicitation material.

\section{Table 4}

\begin{tabular}{|c|c|}
\hline $\begin{array}{l}\text { Annual Fee } \\
\text { Account Set-up Fee } \\
\text { Program Fee } \\
\text { Participation Fee } \\
\text { Additional Card Fee } \\
\text { Account Maintenance Fee } \\
\text { on Closed Accounts }\end{array}$ & $\begin{array}{l}\text { NOTEE: some of these set-up and maintenance feeswill be } \\
\text { assessed before you begin using your card and will reduce the } \\
\text { amount of credit you initially have available. For example, if } \\
\text { you are assigned a minimum credit limit of } \$ 250 \text {, your initial } \\
\text { available credit will be only } \$ 68 \text { (or } \$ 53 \text { if you choose to have } \\
\text { an additionalcard). } \\
\$ 60 \\
\$ 30 \text { (one-time fee) } \\
\mathbf{\$ 8 5} \text { (one-time fee) } \\
\mathbf{\$ 8 4} \text { annually ( } \$ 7 \text { per month) } \\
\mathbf{\$ 1 5} \text { annually (if applicable) } \\
\mathbf{\$ 6 0} \text { annually ( } \$ 5 \text { per month on closed accounts with an } \\
\text { outstanding balance of } \$ 30 \text { or more) }\end{array}$ \\
\hline $\begin{array}{l}\text { Transaction Fees } \\
\text { Balance Transfer } \\
\text { Cash Advance }\end{array}$ & $\begin{array}{l}\text { Either } \$ 5 \text { or } 3 \% \text { of the amount of each transfer, which is greater } \\
\text { (max fee: } \$ 100 \text { ) } \\
\text { Either } \$ 5 \text { or } 3 \% \text { of the amount of each cash advance, whichever } \\
\text { is greater. }\end{array}$ \\
\hline$\frac{\text { Penalty Fees }}{\text { Late Payment }}$ & $\begin{array}{l}\text { \$29 if balance is less than or equal to } \$ 1,000 \text {; } \\
\text { \$35 if balance is more than } \$ 1,000 \text { (Your APRs may also } \\
\text { increase; see Penalty APR section above.) } \\
\text { \$29 (Your APRs may also increase see Penalty APR sectron } \\
\text { above.) } \\
\text { \$35 (Your APRs may also increases see Penalty APR section } \\
\text { above.) }\end{array}$ \\
\hline
\end{tabular}




\section{B. Proposed Changes for Credit Card Billing Statements}

Once a consumer has responded to a credit card solicitation and is using the card, the most relevant regular communication from the issuing bank is the monthly statement. A credit card statement includes transaction details, previous month’s payments, ending balance, payment due date and minimum required payment, interest rate(s) applied, and any fees charged. Informed by consumer testing and other research, the proposed revisions to Regulation $\mathrm{Z}$ are intended to clarify the information presented on the statement in ways that will improve consumers' understanding of the costs associated with credit card use. As Hogarth noted, several of these charges may also help reinforce the behaviors identified in her research that lead to lower borrowing costs. In her discussion she highlighted four areas addressed in the proposed revisions: late payments, notice of minimum payments, changes to account terms, and multiple fee/interest rate categories.

\section{Late payments}

Hogarth's earlier research identified paying bills on time to be one of the more important

consumer behaviors that lead to lower borrowing costs. In addition to this long-term benefit, there are also significant direct costs associated with not making credit card payments on time in the form of fees and, possibly, penalty APRs.

Table 5 illustrates how several of the proposed changes would be represented in a monthly billing statement. First, the proposal would require that the payment due date be displayed prominently on the first and front page of the statement. Consumer testing indicated that many cardholders often miss the payment due date when it is included on a subsequent or reverse page in the statement. To further emphasize the importance of making timely payments, the proposed disclosure format also requires a late payment warning. The warning must be included in a space near the payment due date and must describe the fees and penalty rates that may be imposed for late payments. 


\section{*Table 5}

Payment Information

New Balance Information

$\$ 1,784.53$

Minimum Payment Due

Payment Due Date

$\$ 48.00$

4/20/07 (before 2:00pm)

Late Payment Warning. If we do not receive your minimum payment by the date listed above, you may have to pay a \$35 late fee and your APRs may be increased up to the Penalty APR of $28.99 \%$.

Notice about Minimum Payments: IDyou make only the minimum payment each period, you will pay more in interest and it will take you longer to pay off your balance. For example, if you had a balance of $\$ 1,000$ at an interest rate of $17 \%$ and always paid only the minimum required, it would take over 7 years to repay this balance. For an estimate of the time it would take to repay your actual balance making only minimum payments, call 1-800-XXX-XXXX.

\section{Notice of minimum payments}

The second proposed change, notice of minimum payments, is also illustrated in Table 5. As Hogarth explained, there is a strong body of research confirming that many consumers struggle with the concept of compound interest and generally underestimate the amount of time it takes to pay off a loan balance when making low or minimum payments. The new notice is intended to address this financial literacy issue with plain language and an example of how compounding interest can affect the time required for repayment.

\section{Changes to account terms}

While most consumers tend to focus on the interest rate and key fees of credit card pricing when shopping for a new card or reviewing credit card solicitations, they are often less familiar with potential changes in pricing that might occur once they have been using the card. With the expectation that such information, provided in a timely fashion, may encourage consumers to take corrective actions, the proposal would require that creditors "provide advance written notice of some changes to the terms of an open end plan.” An example that highlights a change in the APR charged for purchases and new late payment fees is shown in Table 6. An important aspect of the proposed disclosure is the requirement that such a notice be sent at least 
45 days before the changes go into effect as opposed to the current 15-day time limit. This extra time is intended to give borrowers more opportunity to explore alternatives or otherwise change behaviors in order to qualify for lower-cost credit.

\section{*Table 6}

Important Changes to Your Account Terms

The following is a summary of changes that are being made to your account terms. You have the right to opt out of these changes. For more detailed information, please refer to the booklet enclosed with this statement. The effective date of these changes is 5/10/07. Note: The change to your APR for purchases described below will not go into effect at this time if you are already being charged a high Penalty APR on purchases. This change will go into effect when the Penalty APR no longer applies.

\begin{tabular}{|l|l|}
\hline \multicolumn{2}{|c|}{ Revised Terms, as of 5/10/07 } \\
\hline APR for Purchases & $16.99 \%$ \\
\hline Late Payment Fee & $\begin{array}{l}\text { \$32 if your balance is less than or equal to \$1,000; } \\
\text { \$39 if your balance is more than \$1,000 }\end{array}$ \\
\hline
\end{tabular}

\section{Multiple fee/interest rate categories}

In recent years, credit card lenders have created a range of new fee categories and differentiated interest rates for different kinds of transactions. In an effort to make these costs more transparent, the proposed regulation requires that a summary of fees and interest charges be listed separately on the statement, along with year-to-date totals for each.

Table 7 provides an example of these proposed changes, including itemized fees. Under the heading "Fees," transaction-based charges would be identified with the term "Transaction Fee.” This change will allow consumers to differentiate between types of fees, such as late fees and balance transfer fees, which would provide consumers with a clearer understanding of the origin and consequences of each charge. Similarly, interest charged on the account would be listed under a separate heading, "Interest Charged.” The two types of interest rate charges Hogarth mentioned were for purchases and cash advances. 
The proposed regulation would also require that the dollar amount associated with fees and those with interest charges be totaled independently. This would allow consumers to easily decipher how much they are paying in fees and how much they are paying in interest charges over each period. Hogarth also noted that year-to-date totals would be listed for each of the sections, total fees, and total interest charged.

The clear presentation of fees charged, especially the disclosure of year-to-date totals, is intended to emphasize the costs of borrowing and fees, potentially leading some consumers to alter their behaviors and reduce their cost of using credit cards.

\begin{tabular}{|l|r|}
\hline *Table 7 & Fees \\
\hline Late Fee & $\$ 35.00$ \\
Cash Advance Fee*Transaction Fee* & $\$ 5.00$ \\
Balance Transfer Fee *Transaction Fe* & $\$ 23.55$ \\
Cash Advance Fee *Transaction Fee* & $\$ 5.90$ \\
TOTAL FEES FOR THIS PERIOD & $\$ \mathbf{6 9 . 4 5}$ \\
\hline Interest Charged & $\$ 6.31$ \\
\hline Interest Charge on Purchases & $\$ 4.58$ \\
Interest Charged on Cash Advances & $\mathbf{\$ 1 0 . 8 9}$ \\
TOTAL INTEREST FOR THIS PERIOD & $\$ 90.14$ \\
\hline 2007 Totals Year-to-Date & $\$ 18.27$ \\
\hline Total fees charged in 2007 & \\
Total interest charged in 2007 & \\
\hline
\end{tabular}

\section{Conclusion}

The proposed changes to credit card solicitations and billing statements are the products of a multi-year review by Federal Reserve staff and extensive consumer testing to gauge the effectiveness and consumers' comprehension of different types of disclosure forms. Simplifying the language describing variable APRs, clearly disclosing payment allocation methods, and itemizing fees are a few of the proposed changes Hogarth discussed at the workshop. As part of consumer testing, the Federal Reserve Board used focus groups and in-depth interviews, a process that aided in developing proposed rules that can both reduce confusion about certain credit card practices and increase transparency of fees and other charges. 
Hogarth's earlier research uncovered five key behaviors that may affect the borrowing rate consumers are charged: paying off credit card balances, paying bills on time, shopping for credit, becoming more financially educated, and decreasing credit utilization. Many of the proposed changes to Regulation Z made by the Federal Reserve Board can be directly tied to one or more behaviors identified by Hogarth and her co-authors in their research. To the extent that the proposed changes in Regulation $\mathrm{Z}$ provide information that might help consumers alter their behaviors and lower their cost of credit card use, the amendments will serve to re-enforce the basic principles behind TILA: "to promote the informed use of consumer credit." 